\title{
PENGARUH ANALISIS FIXED SAMPLE SIZED SAMPLING, STOP OR GO SAMPLING, DAN DISCOVERY SAMPLING TERHADAP TINGKAT EFEKTIVITAS SISTEM PENGENDALIAN INTERN ATAS AKTIVITAS PEMBUATAN AKTA FIDUSIA DAN WAARMERKING PADA KANTOR NOTARIS DEWI MEUTIA KOTA PROBOLINGGO
}

\author{
Mutimmah Rustianawati \\ Febri Yanti Dwita \\ Email: mutimmah.rustiana@gmail.com \\ Universitas Panca Marga Probolinggo
}

\begin{abstract}
This research aims to determine the level of effectiveness the company's internal control system if measured by using the analysis of Fixed Sample Sized Sampling, Stop Or Go Sampling, and Discovery Sampling. The subject of this research is Kantor Notaris of DewiMeutiaCiptaNingrum, S.H., M.H., M.Kn which used as research sample. This research data is obtained from direct observation of the transaction evidence that has been selected by using purposive sampling with certain criteria. The analysis technique used is quantitative descriptive technique. The steps of data analysis techniques used in this study is to calculate the effectiveness level of internal control system using Fixed Sample Sized Sampling, calculate the effectiveness of internal control system using Stop Or Go Sampling, and calculate the effectiveness level of internal control system using the Discovery Sampling testing procedure. The result of data processing shows that Internal Control System of DewiMeutiaProbolinggo Notary Office is considered effective.
\end{abstract}

Keywords: Fixed Sample Sized Sampling, Stop Or Go Sampling, Discovery Sampling and Level of Effectiveness of Internal Control System

\section{ABSTRAK}

Penelitian ini bertujuan untuk mengetahui tingkat efektivitas sistem pengendalian intern perusahaan jika diukur dengan menggunakan metode analisis Fixed Sample Sized Sampling, Stop Or Go Sampling, dan Discovery Sampling. Subjek penelitian ini adalah Kantor Notaris Dewi Meutia Cipta Ningrum, S.H., M.H., M.Kn yang dijadikan sampel penelitian. Data penelitian ini diperoleh dari pengamatan secara langsung terhadap bukti transaksi yang telah dipilih menggunakan purposive sampling dengan criteria tertentu.Tekhnikanalisis yang digunakan adalah tekhnik deskriptif kuantitatif. Adapun langkah-langkah tekhnikanalisis data yang digunakan dalam penelitian ini yaitu menghitung tingkat efektivitas sistem pengendalian intern dengan menggunakan prosedur pengujian Fixed Sample Sized Sampling, menghitung tingkat efektivitas sistem pengendalian intern dengan menggunakan prosedur pengujian Stop Or Go Sampling, dan menghitung tingkat efektivitas sistem pengendalian intern dengan menggunakan prosedur pengujian Discovery Sampling.Hasil pengolahan data menunjukkan bahwa Sistem Pengendalian Intern Kantor Notaris Dewi Meutia Kota Probolinggo dinilai telah efektif. 


\section{Kata Kunci: Fixed Sample Sized Sampling, Stop Or Go Sampling, Discovery Sampling danTingkat EfektivitasSistemPengendalian Intern}

\section{PENDAHULUAN}

Salah satu unsur penting dalam sistem pengendalian internal adalah unsur lingkungan pengendalian. Lingkungan Pengendalian merupakan kondisi yang mempengaruhi kesadaran dari pihak-pihak yang bertanggung jawab atas efektifitas pengendalian suatu perusahaan atau organisasi. Pemahaman lingkungan pengendalian menjadi hal yang penting bagi anggota organisasi yang terlibat dalam struktur pengendalian intern suatu entitas. Kebijakan yang ditetapkan oleh manajemen puncak sangat berpengaruh terhadap keakuratan data dalam laporan keuangan yang disusun dari proses akuntansi suatu entitas yang didukung dengan sistem pengendalian yang handal untuk menghindari terjadinya atau untuk mencegah timbulnya kecurangan (fraud) dalam penggunaan harta atau aset perusahaan.

Semua perusahaan harus mampu mendeteksi serta mengurangi potensi risiko terjadinya kecurangan secara dini terhadap aktivitas dan kegiatan operasional usahanya dengan membangun sistem pengendalian intern yang handal serta melakukan pengawasan yang memadai. Penyelenggaraan pengendalian intern yang efektif dapat memberikan keyakinan yang memadai terhadap keakuratan data yang disajikan dalam laporan keuangan suatu perusahaan.

Unsur lain dari sistem pengendalian intern adalah informasi dan komunikasi, suatu sistem informasi sangat penting untuk membangun komunikasi dalam suatu perusahaan. Perusahaan yang tidak mampu membangun sistem informasi dan komunikasi maka perusahaan tersebut akan mengalami kesulitan didalam menjalankan atau meneruskan kegiatan usahanya. Efektifitas suatu perusahaan dalam melangsungkan usahanya dapat dilihat dari kemampuan perusahaan dalam melaksanakan sistem pengendalian yang dibangun dalam perusahaan tersebut. Sebagai salah satu unsur sistem pengendalian intern, informasi dan komunikasi merupakan aktivitas menyediakan, memanfaatkan berbagai bentuk sarana komunikasi; dan mengelola, mengembangkan, serta memperbarui sistem informasi secara terus menerus, hal tersebut dapat membantu perusahaan dalam menjalankan usahanya.

Berdasarkan Standar Pekerjaan Lapangan kedua dalam Mulyadi (2011:16) yang berbunyi: "Pemahaman yang memadai atas pengendalian intern harus diperoleh untuk merencanakan audit dan menentukan sifat, saat, dan lingkup pengujian yang akan dilakukan". Untuk memahami sistem pengendalian intern perusahaan, lebih dulu Auditor harus memahami sistem perencanaan strategis perusahaan, yaitu bagaimana stategi perusahaan dalam mencapai tujuan dan sasaran perusahaan serta program yang dijalan dalam mencapai tujuan dan sasaran tersebut, dengan memperoleh pemahaman mengenai sistem perencanaan strategis perusahaan maka auditor akan lebih mudah memahami sistem pengendalian perusahaan. Pemahaman terhadap kekuatan dan kelemahan sistem pengendalian intern yang ada dalam suatu perusahan maka auditor dapat membuat rencana audit dengan menyusun prosedur pengujian tingkat efektivitas sistem 
pengendalian intern terhadap suatu bukti transaksi yang dilakukan dalam kegiatan operasional perusahaan.

Pengujian pengendalian mengenai ketaatan terhadap sistem pengendalian intern dalam proses pembuatan akta fidusia dan Waarmerking yang dilakukan selama pekerjaan lapangan diharapkan dapat menghasilkan bukti yang akurat mengenai ketepatan dan konsistensi penerapan suatu kebijakan pengendalian intern. Sesuai dengan ISA (International Standards on Auditing) Nomor 315 Alinea 13 dalam Theodorus (2014:127) "Ketika memperoleh pemahaman tentang pengendalian yang relevan dengan audit, auditor wajib mengevaluasi rancangan pengendalian tersebut dan menentukan apakah pengendalian tersebut memang diimplementasi, dengan melakukan prosedur tertentu disamping bertanya kepada karyawan entitas".

\section{METODE PENELITIAN \\ JenisPenelitian}

Jenis penelitian yang digunakan dalam penelitian ini adalah penelitian deskriptif. Penelitian deskriptif merupakan suatu rumusan masalah yang berkenaan dengan pertanyaan keberadaan variabel mandiri, baik pada satu variabel atau lebih (variabel yang berdiri sendiri). Penelitian ini menggunakan pendekatan kausal yaitu hubungan yang bersifat sebab akibat dan terdapat variabel yang mempengaruhi juga variabel yang dipengaruhi.

\section{Sumber Data}

Sumber data yang digunakan dalam penelitian ini berupa data sekunder yang berupa bukti kwitansi atas aktivitas pembuatan akta fidusia dan Waarmerking dari bulan Januari tahun 2017-bulan April 2018.

\section{Metode Pengumpulan Data}

Metode pengumpulan data yang digunakan dalam penelitian ini adalah metode observasi. Dalam hal ini, catatan atau dokumen perusahaan yang dimaksud adalah bukti kwitansi atas aktivitas pembuatan akta fidusia dan Waarmerking dari bulan Januari tahun 2017-bulan April 2018.

\section{Metode Analisis Data}

Dalam penelitian ini, peneliti menggunakan tekhnik deskriptif yaitu menganalisis data dengan cara menjelaskan atau menggambarkan data yang telah terkumpul sebagai mana adanya tanpa bermaksud membuat kesimpulan yang berlaku untuk umum atau generalisasi. Adapun langkah-langkah tekhnik analisis data yang digunakan dalam penelitian ini adalah sebagai berikut :pertama menghitung tingkat efektivitas sistem pengendalian intern dengan menggunakan prosedur pengujian Fixed Sample Sized Sampling, kedua menghitung tingkat efektivitas sistem pengendalian intern dengan menggunakan prosedur pengujian Stop Or Go Sampling, dan menghitung tingkat efektivitas sistem pengendalian intern dengan menggunakan prosedur pengujian Discovery Sampling.

\section{HASIL PENELITIAN}


Analisis Fixed Sample Sized Sampling pada Kantor Notaris Dewi Meutia Kota Probolinggo.

Tabel 1

Evaluasi Hasil Pemeriksaan Fixed Sample Sized Sampling

\begin{tabular}{|c|l|l|l|l|l|}
\hline $\begin{array}{c}\text { No } \\
\text { attribut }\end{array}$ & Jumlah Sampel & Jumlah Kesalahan & AUPL & DUPL & $\begin{array}{c}\text { Efektif } \\
\text { (Ya/Tidak) }\end{array}$ \\
\hline 1 & 100 & 0 & $3 \%$ & $5 \%$ & Ya \\
\hline 2 & 100 & 0 & $3 \%$ & $5 \%$ & Ya \\
\hline 3 & 100 & 1 & $4 \%$ & $5 \%$ & Ya \\
\hline
\end{tabular}

Sumber : Data diolah Peneliti, 2018

Data diatas merupakan data olahan hasil evaluasi dengan menggunakan Fixed Sample Sized Sampling terhadap tiga attribute yang terdiri dari: pertama Nomor urut tercetak bukti kwitansi atas aktivitas pembuatan akta fidusia dan waarmerking, kedua tanda tangan otorisasi bukti kwitansi atas aktivitas pembuatan akta fidusia dan waarmerking, dan ketiga tembusan bukti kwitansi atas aktivitas pembuatan akta fidusia dan waarmerking. Pada pemeriksaan attribute yang pertama tidak terdapat kesalahan dari jumlah sampel sebanyak 100 kwitansi, sehingga AUPL (Achieved Upper Precision Limit) sebesar 3\% lebih kecil dari DUPL (Desired Upper Precision Limit) sebesar 4\%. Untuk attribute kedua dari sebanyak 100 sampel, semua kwitansi yang dilakukan pemeriksaan memiliki tanda tangan/otorisasi langsung dari notaris. Sedangkan pada attribute ketiga, dari 100 sampel yang diuji diperoleh 1 bukti kwitansi yang tidak memiliki tembusan. Hal ini berarti menambah nilai AUPL menjadi 4\% tetapi masih berada dibawah nilai DUPL 50\%, maka ketiga attribute yang diperiksa masih menunjukkan nilai efektif.

\section{Analisis Stop Or Go Sampling pada Kantor Notaris Dewi Meutia Kota Probolinggo}

Tabel 2

Evaluasi Hasil Pemeriksaan Stop or Go Sampling

\begin{tabular}{|c|l|l|l|l|l|}
\hline $\begin{array}{c}\text { No } \\
\text { attribut }\end{array}$ & Jumlah Sampel & Jumlah Kesalahan & AUPL & DUPL & $\begin{array}{c}\text { Efektif } \\
\text { (Ya/Tidak) }\end{array}$ \\
\hline 1 & 96 & 0 & $5 \%$ & $5 \%$ & Ya \\
\hline 2 & 96 & 0 & $5 \%$ & $5 \%$ & Ya \\
\hline 3 & 96 & 1 & $5 \%$ & $5 \%$ & Ya \\
\hline
\end{tabular}

Sumber : Data diolah peneliti, 2018

Tabel diatas menggambarkan hasil evaluasi dengan menggunakan Stop or Go Sampling terhadap tiga attribute yang terdiri dari: pertama Nomor urut tercetak bukti kwitansi atas aktivitas pembuatan akta fidusia dan waarmerking, kedua tanda tangan otorisasi bukti kwitansi atas aktivitas pembuatan akta fidusia 
dan waarmerking, dan ketiga tembusan bukti kwitansi atas aktivitas pembuatan akta fidusia dan waarmerking. Pada pemeriksaan attribute yang pertama tidak terdapat kesalahan dari jumlah sampel sebanyak 96 kwitansi, sehingga AUPL (Achieved Upper Precision Limit) sebesar 5\% lebih kecil dari DUPL (Desired Upper Precision Limit) sebesar 5\%. Untuk attribute kedua dari sebanyak 96 sampel, semua kwitansi yang dilakukan pemeriksaan memiliki tanda tangan/otorisasi langsung dari notaris dan tidak terdapat bukti transaksi (kwitansi) yang mengalami kesalahan. Sedangkan pada attribute ketiga, dari 96 sampel yang diuji diperoleh 1 bukti transaksi (kwitansi) yang tidak memiliki tembusan. Nilai AUPL tetap sama dengan nilai DUPL yaitu sebesar 5\% karena kesalahan ditemukan pada saat jumlah sampel yang diambil sejumlah 60 sampel. Pada Stop Or Go Sampling apabila pada sampel minimum ditemukan kesalahan, maka jumlah sampel ditambah jumlahnya. Meskipun nilai AUPL sama dengan nilai DUPL, sistem pengendalian intern masih dapat dikategorikan efektif.

\section{Analisis Discovery Sampling pada Kantor Notaris Dewi Meutia Kota Probolinggo}

Tabel 3

Evaluasi Hasil Pemeriksaan Discovery Sampling

\begin{tabular}{|c|l|l|l|l|l|}
\hline $\begin{array}{c}\text { No } \\
\text { attribut }\end{array}$ & Jumlah Sampel & Jumlah Kesalahan & AUPL & DUPL & $\begin{array}{c}\text { Efektif } \\
\text { (Ya/Tidak) }\end{array}$ \\
\hline 1 & 70 & 0 & $1 \%$ & $1 \%$ & Ya \\
\hline 2 & 70 & 0 & $1 \%$ & $1 \%$ & Ya \\
\hline 3 & 70 & 0 & $1 \%$ & $1 \%$ & Ya \\
\hline
\end{tabular}

Sumber : Data diolah peneliti, 2018

Tabel diatas menggambarkan hasil evaluasi dengan menggunakan Discovery Sampling terhadap tiga attribute yang terdiri dari: pertama Nomor urut tercetak bukti kwitansi atas aktivitas pembuatan akta fidusia dan waarmerking, tanda tangan otorisasi bukti kwitansi atas aktivitas pembuatan akta fidusia dan waarmerking, dan tembusan bukti kwitansi atas aktivitas pembuatan akta fidusia dan waarmerking. Pada pemeriksaan attribute yang pertama tidak terdapat kesalahan dari jumlah sampel sebanyak 70 kwitansi, sehingga nilai AUPL (Achieved Upper Precision Limit) sebesar 1\% sama dengan DUPL (Desired Upper Precision Limit) yaitu sebesar 1\%. Apabila nilai AUPL sama dengan nilai DUPL, sistem pengendalian intern masih dapat dikategorikan efektif.

\section{Hasil Uji Asumsi Klasik}

Uji asumsi klasik yang dilakukan dengan uji normalitas diperoleh nilai $p$-value yaitu Asymp. Sig. (2-tailed) bernilai 0,093 > 0,05 sehingga disimpulkan bahwa residual telah memenuhi asumsi distribusi normal. 
Uji Multi kolinearitas diketahui bahwavariabel Fixed Sample Sized Sampling $\left(\mathrm{X}_{1}\right)$ memilikinilai tolerance sebesar 0,694 dengan nilai VIF $(1,441)<10$, variabelStop Or Go Sampling $\left(\mathrm{X}_{2}\right)$ dengan nilai tolerance $(0,642)$ dengan nilai VIF $(1,557)<$ 10 , variable Discovery Sampling $\left(\mathrm{X}_{3}\right)$ dengan nilai tolerance 0,512 dan nilai VIF sebesar $(1,952)<10$. Dalam hal ini berarti bahwa ketiga variable tersebut tidak memiliki masalah multikolinearitas. Hasil uji auto korelasi menunjukkan tidak adanya masalah auto korelasi dikarenakan nilai DW berada diantara -2 dan +2 atau $-2<\mathrm{DW} \leq+2$ yaitu sebesar 0,225 .

Berdasarkan hasil uji koefisien determinasi, diketahui bahwa nilai adjusted $R^{2}$ atau koefisien determinasi yang telah disesuaikan adalah 0,529. Hal itu menunjukkan 53\% variasi Tingkat Efektivitas dapat dijelaskan dengan variable Fixed Sample Sized Sampling, Stop Or Go Sampling, danDiscovery Sampling. Sedangkan $47 \%$ dijelaskan oleh factor lain diluar model.

\section{Hasil Uji Hipotesis}

Nilai uji t (uji parsial) menunjukkan thitung untuk variabel Fixed Sample Sized Sampling adalah sebesar $1.693<1,985$ (t tabel sebesar 98-1-3=94, $\alpha$ 5\%). Untuk variabel Stop Or Go Sampling t hitung sebesar -3,918<1,985. Sedangkan variabel Discovery Sampling memiliki t hitung sebesar $-5.491<1,985$. Kesimpulannya adalah $\mathrm{t}$ hitung $<\mathrm{t}$ tabel, maka H0 diterima dan Ha ditolak.

Variabel bebas yang mempunyai pengaruh paling dominan terhadap variabel terikat dilihat pada Standardized Coefficient Beta. Nilai Standardized Coefficient Beta yang paling besar pada sata output SPSS adalah sebesar 0,142 yang dimiliki oleh variabel Fixed Sample Sized Sampling. Artinya variabel bebas yang berpengaruh paling dominan terhadap tingkat efektivitas adalah Fixed Sample Sized Sampling.

\section{PEMBAHASAN}

Dari hasil analisis ketiga variable diperoleh bahwa sistem pengendalian intern pada Kantor Notaris Dewi Meutia Kota Probolinggo cukup efektif dengan menggunakan pengujian pengendalian Fixed Sample Sized Sampling, dan diperoleh hasil AUPL (Achieved Upper Precision Limit) yang lebih kecildari DUPL (Dessired Upper Precision Limit) yaitu sebesar 4\% dari 100 sampel. Untuk pengujian pengendalian menggunakan variabel Stop Or Go Sampling diperoleh tingkat efektivitas sistem pengendalian intern sebesar 5\% dari 96 sampel yang berarti AUPL = DUPL, maka sistem pengendalian intern pada Kantor Notaris Dewi Meutia Kota Probolinggo sudah efektif. Dari pengujian pengendalian variabel Discovery Sampling diperoleh AUPL (1\%) = DUPL (1\%) dari 70 sampel, hal ini berarti dapat dinilai bahwa pengujian pengendalian sistem pengendalian intern dengan menggunakan Discovery Sampling pada Kantor Notaris DewiMeutia Kota Probolinggo telah efektif.

Dari uji asumsi klasik yang dilakukan dengan uji normalitas diperoleh nilaip-value yaitu Asymp. Sig. (2-tailed) bernilai 0,093> 0,05 sehingga disimpulkan bahwa residual telah memenuhi asumsi distribusi normal. Uji Multikolinearitas diketahui bahwa variabelFixed Sample Sized Sampling $\left(\mathrm{X}_{1}\right)$ memiliki nilai tolerance sebesar 0,694 dengan nilai $\operatorname{VIF}(1,441)<10$, variable 
Stop Or Go Sampling $\left(\mathrm{X}_{2}\right)$ dengan nilai tolerance $(0,642)$ dengan nilai VIF $(1,557)<10$, variable Discovery Sampling $\left(\mathrm{X}_{3}\right)$ dengan nilai tolerance 0,512 dan nilai VIF sebesar $(1,952)<10$. Dalam hal ini berarti bahwa ketiga variable tersebut tidak memiliki masalah multikolinearitas. Hasil uji auto korelasi menunjukkan tidak adanya masalah auto korelasi dikarenakan nilai DW berada diantara -2 dan +2 atau $-2<\mathrm{DW} \leq+2$ yaitu sebesar 0,225 . Berdasarkan hasil uji koefisien determinasi, diketahui bahwa nilai adjusted $R^{2}$ atau koefisien determinasi yang telah disesuaikan adalah 0,529. Hal itu menunjukkan 53\% variasi Tingkat Efektivitas dapat dijelaskan dengan variabel Fixed Sample Sized Sampling, Stop Or Go Sampling, dan Discovery Sampling. Sedangkan 47\% dijelaskan oleh faktor lain diluar variabel.

Dari uji parsial yang dilakukan menunjukkan bahwa secara parsial Fixed Sample Sized, Stop Or Go Sampling dan Discovery Sampling tidak berpengaruh secara signifikan terhadap tingkat efektivitas sistem pengendalian intern pada Kantor Notaris Dewi Meutia Kota Probolinggo.

Dari hasil uji t dapat dilihat nilai Standardized Coefficient Beta yang paling besar pada sata output SPSS adalah sebesar 0,142 yang dimiliki oleh variabel Fixed Sample Sized Sampling. Artinya variabel bebas yang berpengaruh paling dominan terhadap tingkat efektivitas adalah Fixed Sample Sized Sampling.

\section{KESIMPULAN}

Berdasarkan analisis dan pembahasan di atas, maka dapat disimpulkan bahwa Sistem pengendalian intern terhadap aktivitas pembuatan akta fidusia dan waarmerking Kantor Notaris Dewi Meutia Kota Probolinggo dinilai telah efektif, baik menggunakan prosedur pengujian pengendalian Fixed Sample Sized Sampling, Stop Or Go Sampling, maupun menggunakan pengujian Discovery Sampling.

Sedangkan berdasarkan uji parsial terhadap tingkat efektivitas sistem pengendalian intern pada Kantor Notaris Dewi Meutia Kota Probolinggo menunjukkan bahwa secara parsial Fixed Sample Sized, Stop Or Go Sampling dan Discovery Sampling tidak berpengaruh secara signifikan'

Sedangkan dari hasil uji t nilai Standardized Coefficient Beta yang paling besar pada sata output SPSS adalah sebesar 0,142 yang dimiliki oleh variabel Fixed Sample Sized Sampling. Artinya variabel bebas yang berpengaruh paling dominan terhadap tingkat efektivitas adalah Fixed Sample Sized Sampling.

\section{DAFTAR PUSTAKA}

Arikunto, S. (2013). Prosedur Penelitian Suatu Pendekatan Praktik. Jakarta: Rineka Cipta.

Azwar, S. (2012). Metode Penelitian. Yogyakarta: Pustaka Pelajar.

Hery. (2010). Auditing I Dasar-Dasar Pemeriksaaan Akuntansi. Jakarta: Kencana Prenada Media Group.

Jusup, H. (2010). Auditing (Pengauditan). Yogyakarta: Sekolah Tinggi Ilmu Ekonomi Ykpn.

Mahmudi. (2015). Manajemen Kinerja Sektor Publik Edisi Ketiga. Yogyakarta: Unit Penerbitan Sekolah Tinggi Ilmu Manajemen Ykpn. 
Meldawati, L. (2017). Penerapan Attribute Sampling Pada Pengujian Kepatuhan Struktur Pengendalian Intern Terhadap Transaksi Pembelian (Studi Kasus Hotel Sahid Raya Yogyakarta).Jurnal Analisa Akuntansi Dan Perpajakan, Volume 1, Nomer 2.115-129. Diunduh Pada 22 Januari 2018 Pukul 13:18 Wib.

Mulyadi. (2011). Auditing Buku 1 Edisi 6. Jakarta: Salemba Empat. . (2014).Sistem Akuntansi. Jakarta: Salemba Empat.

Oktriyuono, D. S. (2008). Evaluasi Sistem Akuntansi Persediaan Obat (Studi Kasus Pada Bidang Kedokteran Dan Kesehatan Polda Diy).Skripsi Program Studi Akuntansi Jurusan Akuntansi Fakultas Ekonomi Universitas Sanata Dharma Yogyakarta.Diunduh Pada 29 Januari 2018 Pukul 15:53 Wib.

Purwanto, Suharyadi. (2009). Statistika Untuk Ekonomi Dan Keuangan Modern Edisi 2. Jakarta: Salemba Empat.

Priyatno. (2008). Mandiribelajar Spss (Statistical Product And Service Solution). Yogyakarta: Media Kom.

Prowoto, B. (2016). Analisis Regresi Dalam Penelitian Ekonomi \& Bisnis. Jakarta: Pt Rajagrafindo Persada.

Ratna, Nyoman Kutha. (2010). Metodologi Penelitian Kajian Budaya Dan Ilmu Sosial Humaniora Pada Umumnya. Yogyakarta: Pustaka Pelajar.

Sugiyono. (2015). Metode Penelitian Kuantitatif, Kualitatif, Dan R\&D. Bandung: Alfabeta .

Sukiranto. (2015). Penerapan Attribute Sampling Pada Pengujian Sistem Pengendalian Internal Atas Aktivitas Pembelian Obat Kimia (Studi Kasus Pt Carusrin).Jurnal Penelitian, Pengembangan Ilmu Manajemen Dan Akuntansi Stie.651-659. Diunduh Pada 08 Desember 2016 Pukul 13:04 Wib.

Tuanakotta, Theodorus. M. (2014). Auditing Berbasis Isa (International Standards On Auditing).Jakarta: Salemba Empat.

Wild, K. S. (2013). Analisis Laporan Keuangan Financial Statement Analysis. Jakarta: Salemba Empat.

Yurizal. (2015). Aspek Pidana Dalam Undang-Undang No. 42 Tahun 1999 Tentang Jaminan Fidusia. Malang: Media Nusa Creative. 